\title{
The Impact of Demographic Factors On Financial Flexibility of Enterprise
}

\author{
A Perspective of Senior Executives
}

\author{
Luping Wen* \\ School of Economics and Management \\ Jiangxi University of Science and Technology \\ Ganzhou,341000, China \\ 3104513820@qq.com
}

\author{
Wenwen $\mathrm{Wu}$ \\ School of Economics and Management \\ Jiangxi University of Science and Technology \\ Ganzhou, 341000, China \\ zensoyou@163.com
}

\begin{abstract}
In recent years, the global economic uncertainty has increased and the fluctuation has become more and more intense. How to maintain sufficient financial flexibility to deal with the uncertainty of the market and achieve stable development is the current focus of accounting circles. It is also an area that our government and enterprises need to seriously consider and study. Based on the demographic factors of senior executives, this paper chooses the gender, age and education of executives as indicators, and takes the A-share non-financial and insurance listed companies from 2013 to 2017 as research samples. Through correlation analysis, multiple regression analysis and robustness analysis, this paper studies the impact of the demographic factors of senior executives on financial flexibility. The results showed that the proportion of women in top management team in the sample of state-owned enterprises had a negative impact on corporate financial flexibility, while the proportion of women in non-state-owned enterprises had a positive impact; the average age of top management team had no significant impact on corporate financial flexibility; and the average degree of top management had a positive impact on corporate financial flexibility.
\end{abstract}

Keywords-Financial Flexibility; Background characteristics of senior executives; Upper Echelons Theory

\section{INTRODUCTION}

In recent years, the global economic environment has become more uncertain, trade frictions have increased, political crises in Europe have become more frequent, and world economic recovery has been sluggish. In order to survive in the uncertain market environment, enterprises must maintain adequate financial flexibility to cope with market uncertainty. Before the crisis, maintaining adequate financial flexibility can not only enable enterprises to get out of financial difficulties faster, but also enable enterprises to grasp investment opportunities in a timely manner, so as to obtain higher benefits.

An important feature of modern enterprise system is the separation of two rights, that is, the separation of ownership and management. The owner entrusts agents to run the company, and the management of the enterprise is generally controlled by the company's senior management. The demographic and psychological characteristics of senior executives will influence their decision-making behavior to some extent. As irrational people, senior executives always have their own characteristics in their decision-making, and the demographic factors of senior executives will affect the financial behavior and non-financial behavior of enterprises. The financial flexibility of an enterprise will be affected by the financial behavior of the company. Therefore, the characteristics of senior executives will inevitably affect the financial flexibility of the enterprise. The psychological characteristics of senior executives are difficult to measure, while the demographic characteristics such as gender, age and education background, which are easy to measure, and are closely related to their values and cognitive abilities. Therefore, it is worth further exploration to study the relationship between senior executives' measurable background characteristic variables and enterprises' financial flexibility.

The research content of this paper is the impact of demographic factors of senior executives on the financial flexibility of enterprises. It is of certain theoretical and practical significance to study the upper echelons theory and relevant theories of financial flexibility.(1) from the perspective of theoretical significance: first of all, the academic research on financial flexibility has just started, and there is still lot of space for improvement. Secondly, domestic and foreign scholars' researches on financial flexibility mostly focus on the relationship between financial flexibility and capital structure, the influence of financial flexibility on investment level and investment efficiency, and the influence of financial flexibility on enterprise value. This paper studies the influence of senior executives' gender, age and education background characteristics on corporate financial flexibility, which can provide some support for the research of this topic to some extent. (2) from the perspective of practical significance: it is of great practical significance to trace the research on financial flexibility back to the background characteristics of corporate behavioral subjects, and to study the influence of their background characteristics on financial flexibility for better senior management team building of enterprises. 


\section{LITERATURE REVIEW}

\section{A. Demographic factors of senior executives}

Senior executives are the core figures in the operation of enterprises and can exert great influence on the strategic selection and decision-making of enterprises. The upper echelons theory proposed [1] argued that the demographic characteristics of senior management have an important impact on corporate decision-making. Since then, many scholars at home and abroad have begun to study the influence of senior executives' demographic characteristics on corporate financial behavior and corporate value. This paper reviews the previous literature on executive's gender, age and education characteristics.

In terms of the gender characteristics of senior executives: Krishnan \& Park [2] pointed out that gender differences in senior executives would affect their behaviors and management styles. The research of $\mathrm{He}$ weifeng and Liu qiliang [3] indicated that executive gender has a positive impact on corporate financial restatement. Subsequently, Srinidhi [4] found that the presence of female directors had a positive impact on the earnings quality of enterprises. Yang lin and Yang qian [5] pointed out that the proportion of male in senior management team has a significant positive correlation with the probability and mode of enterprise' merger and acquisition. Zhang zhaoguo, xiang shouren and Cao danting [6] investigated the relationship between heterogeneity of senior management teams and CSR(Corporate Social Responsibility), and pointed out that heterogeneity of senior management teams in terms of gender is positively correlated with CSR.

In terms of the age characteristics of senior executives, Waelchli \& Zeller [7] pointed out that the age of the chairman would have a significant negative impact on corporate performance. Lu xin, zhang lele and Li huimin [8] concluded that the average age of senior management team has a positive impact on investment efficiency in the study of background characteristics of senior management team and investment efficiency of enterprises. While Li duansheng and Zhou hong [9] found that the average age of executive team is negatively correlated with the quality of internal control of enterprises when they studied the influence of background characteristics of senior executives on the quality of internal control of enterprises.

In terms of the educational characteristics of senior executives, Smith [10] pointed out that the CEO with high education background has more advantages in information collection and processing than the CEO with low education background. Zhang ping [11] studied the relationship between heterogeneity of senior management teams and corporate performance, and concluded that the improvement of education level of senior executives would have a positive effect on the improvement of corporate performance. Yang ruiping, Liang zhangying [12] studied the data of listed real estate companies, and concluded that the education level of senior management team is significantly positively correlated with the quality of internal control. The research of Zhou hong and Li duansheng [13] also pointed out that greater academic heterogeneity of senior management teams can improve the quality of internal control of enterprises.

\section{B. Literature review on financial flexibility}

In terms of the definition of financial flexibility: Graham \& Harvey [14]put forward that financial flexibility is the liability capacity reserved by an enterprise for timely acquisition or use of financial resources in the future; Zhan meisong [15]also showed that financial flexibility means that the company takes relevant actions to adjust the distribution of cash inflows in terms of amount and time, so that the enterprise can better respond to unexpected cash demands and investment opportunities. Gu naikang, Wan xiaoyong and Chen hui [16] pointed out that financial flexibility is a company's ability to grasp opportunities and meet challenges with existing funds and financing capacity.

On the influencing factors of financial flexibility: the research of Billett \& Garfinkel [17] showed that the capital market condition and the cost of issuing bonds are the key factors affecting financial flexibility. Li shixin and Liu ning [18] found that higher accounting robustness in corporate financial reports would increase financing constraints and ultimately reduce the financial flexibility of enterprises. Li yan [19] considered financial flexibility from the perspective of enterprise life cycle, and concluded that "the financial flexibility of enterprises in the initial stage is small, the growth stage is slightly improved, the financial flexibility of enterprises in the mature stage reaches the maximum, and in the decline stage is small". Wang aiqun and Tang wenping [20] pointed out that the higher the environmental uncertainty faced by enterprises, the greater their financial flexibility; Ma chunai [21] analyzed financial flexibility from another perspective, showed that managers' overconfidence can have a significant impact on enterprises' financial flexibility.

On the relationship between financial flexibility and other related concepts: Lie [22] pointed out that the financial flexibility of an enterprise will affect its dividend decision; Marchica \& Mura [23] proved that maintaining high financial flexibility can improve the investment level of enterprises; $\mathrm{Gu}$ naikang, Wan xiaoyong and Chen hui [24] also pointed out that financial flexibility is an important factor affecting the investment and financing decisions of Chinese enterprises. Subsequently, the research of Chen hongbing and Lian yujun [25] showed that financial flexibility can significantly improve the investment capacity of enterprises. Ma chunai and Zhang yafang [26] studied the relationship between financial flexibility and enterprise value, and found that financial flexibility significantly promoted enterprise value. Li yue, Guo zeguang and $\mathrm{Li}$ chengyou [27] pointed out that financial flexibility is conducive to the optimization and adjustment of capital structure.

In general, the research on financial flexibility started late, and mainly focused on the definition and concept of financial flexibility, the influencing factors of financial flexibility, and the relationship between financial flexibility and other related concepts. Research on the demographic factors of senior executives mainly focuses on the characteristics of senior executives on corporate earnings quality, corporate internal audit quality, corporate investment decisions, corporate social responsibility and corporate performance. On the whole, there are few literatures that study the demographic factors and 
financial flexibility of senior executives together. In this paper, the two are combined to explore the influence of such characteristic variables as the proportion of female senior executives, average age and average education background on the financial flexibility of enterprises.

\section{HYPOTHESIS}

Generally speaking, there are big differences between men and women in the way of thinking, values, perspectives and ways of dealing with problems. Women are more risk averse than men. As a result, female executives are more conservative and cautious than their male counterparts when making decisions. The empirical research results of Liu qiliang showed that the higher the proportion of male in the executive team, the more financial restatement behaviors of the enterprise. When Huang \& Kisgen [28] studied the financial and investment decisions made by male and female executives, they found that female executives made fewer acquisitions and issued bonds less frequently than male executives. Furthermore, female executives are less likely to choose risky behaviors. For example, in the research of $\mathrm{Lu}$ xin, $\mathrm{Li}$ minhui and Chen shuo hui [29], the conclusion that male executives can promote the occurrence of corporate financial fraud is drawn. At the same time, women also pay more attention to the fulfillment of social responsibilities. For example, the research of $\mathrm{Xu}$ xixiong and $\mathrm{Li}$ yaoqin [30] showed that the gender difference of senior executives will have a profound impact on the fulfillment of corporate social responsibility. When the proportion of female CEOs or senior executives increases, the quality of corporate social responsibility will be greatly improved. In a word, women's conservative and cautious psychology will reduce the excessive investment of enterprises, which may keep the financial leverage low and the financial flexibility high. Based on the above analysis, this paper proposes hypothesis 1 :

H1: The proportion of women in the executive team is positively correlated with corporate financial flexibility.

Age reflects a person's life and work experience. People of different ages have different perceptions of the same thing, and therefore make different decisions about the same problem. Wiersema \& Bantel [31] pointed out that older executives are more likely to make more conservative decisions. Young executives, on the other hand, are more energetic and eager to prove their talent and strength, so they are less afraid of risks and challenges, and sometimes appear overconfident. He hongqu and Zhao tianzhe [32] pointed out that managers' overconfidence will easily lead to enterprises' overinvestment, which will reduce enterprises' financial flexibility to a certain extent. With the growth of age, senior executives of enterprises have accumulated more work experience, and they can make more comprehensive decisions and more accurate judgments, so as to reduce financial risks for enterprises. When faced with risky projects, older executives are more likely to opt for "safety and security" and invest less in risky projects, thereby maintaining greater financial flexibility and avoiding "late losses." Based on the above analysis, this paper proposes hypothesis 2:

$\mathrm{H} 2$ : The average age of the executive team is positively correlated with financial flexibility of enterprises.
Education level largely reflects a person's ability, because people with higher education are more able to use what they have learned to solve practical problems, have stronger learning ability and more self-discipline. Sun haifa, Yao zhenhua and Yan maosheng [33] pointed out that the positive correlation factor of long-term enterprise performance is the average education level. Cao hongxia [34] pointed out that the chairman of the board with a higher education will conduct a more comprehensive analysis of the information he has before making a decision, and make a correct assessment of the projects to be invested, so as to avoid the occurrence of excessive investment and maintain a higher financial flexibility of the enterprise. The more educated executives are, the more they are able to think globally, identify market risks more quickly, plan cash ahead of time and maintain greater financial flexibility. Based on the above analysis, this paper proposes hypothesis 3 :

H3: The average degree of the executive team is positively correlated with financial flexibility of enterprises.

\section{MODEL}

$\mathrm{FF}=\beta_{0}+\beta_{1}$ Female_Rate $+\beta_{2}$ Avg_Age $+\beta_{3}$ Avg_Degree $+\beta_{4} \mathrm{Siz}$ $\mathrm{e}+\beta_{5} \mathrm{ROE}+\beta_{6}$ Profit $+\beta_{7} \mathrm{IC}+$ Year + Industry $+\varepsilon$

In the model, FF represents the financial flexibility of enterprise. The calculation of financial flexibility in this paper refers to the financial flexibility index method of Ma chunai and Han xinhua [35]; Female_Rate represents the proportion of female in the executive team; Avg_Age represents the average age of the senior executives' team; Avg_Degree is the ratio of the total educational degree of senior executives of listed companies to the number of senior executives. Its value is assigned by Han jing [36], and the value is: $1=$ technical secondary school or below, $2=$ junior college, $3=$ bachelor's degree, $4=$ master's degree, $5=$ doctor's degree or above; The Size of the company is expressed by the natural logarithm of the total assets of the enterprise, namely In. Return on equity (ROE) is the ratio of a company's net profit to its average net assets; The enterprise Profit refers to the ratio of the enterprise's operating interest rate to its operating income; Net cash of operating income (IC) refers to the ratio of net cash flow generated from business activities to total operating income.

\section{EMPIRICAL TEST AND RESULT ANALYSIS}

\section{A. Descriptive Statistics and Correlation Analysis}

This paper firstly conducts descriptive analysis on the demographic factors, financial flexibility and related control variables of senior executives of all sample companies, and then divide all samples into state-owned enterprises and nonstate-owned enterprises according to different property rights. Statistical analysis results are shown in table I and table II 
TABLE I. DESCRIPTIVE STATISTICAL RESULTS OF VARIABLES（ALL SAMPLES)

\begin{tabular}{|l|c|c|c|c|c|c|}
\hline variable & $\mathbf{N}$ & mean & $\mathbf{p 5 0}$ & $\mathbf{s d}$ & $\mathbf{m i n}$ & $\mathbf{m a x}$ \\
\hline FF & 12310 & 1.084 & 0.836 & 0.952 & 0.139 & 6.261 \\
\hline Female_Rate & 12310 & 0.157 & 0.125 & 0.188 & 0.000 & 1.000 \\
\hline Avg_Age & 12310 & 47.606 & 47.500 & 4.264 & 25.000 & 67.000 \\
\hline Avg_Degree & 12310 & 3.243 & 3.267 & 0.542 & 1.000 & 5.000 \\
\hline Size & 12310 & 22.078 & 21.904 & 1.270 & 19.815 & 26.054 \\
\hline ROE & 12310 & 0.076 & 0.075 & 0.096 & -0.353 & 0.341 \\
\hline Profit & 12310 & 0.090 & 0.081 & 0.148 & -0.606 & 0.541 \\
\hline IC & 12310 & 0.086 & 0.080 & 0.187 & -0.715 & 0.670 \\
\hline
\end{tabular}

As shown in Table I, the maximum value of financial flexibility is 6.261 , the minimum value is 0.139 , the average value is 1.084 , and the standard deviation is 0.952 , which is slightly higher than other variables. Among independent variables, the average female executive ratio is 0.157 , which is lower and consistent with the actual situation. The average age of senior executives is 67 at most and 25 at least, with a large age difference and a standard deviation of 4.264, indicating a large degree of dispersion. The average age is 47.606, indicating that the proportion of senior executives in the senior management team of listed companies in China is significant. With respect to record of formal schooling respect, average level is undergraduate course above, but lowest record of formal schooling has technical secondary school and technical secondary school below, highest record of formal schooling is doctor and above, difference is big.

TABLE II. DESCRIPTIVE STATISTICAL RESULTS OF SAMPLES UNDER DIFFERENT PROPERTY RIGHTS

\begin{tabular}{|l|c|c|}
\hline variable & State-owned sample & Non-state-owned sample \\
\hline FF & 0.727 & 1.254 \\
\hline Female_Rate & 0.119 & 0.176 \\
\hline Avg_Age & 49.892 & 46.513 \\
\hline Avg_Degree & 3.394 & 3.171 \\
\hline Size & 22.790 & 21.737 \\
\hline ROE & 0.059 & 0.084 \\
\hline Profit & 0.066 & 0.102 \\
\hline IC & 0.094 & 0.082 \\
\hline
\end{tabular}

According to Table II the average financial flexibility of samples of state-owned enterprises is 0.727 , and that of samples of non-state-owned enterprises is 1.254. In terms of the age characteristics of senior executives, the average age of senior management teams in non-state-owned enterprises is 46.513 and 49.892 in state-owned enterprises. Comparatively speaking, senior executives in non-state-owned enterprises are younger. However, in terms of the proportion of women in the senior management team, the proportion of women in the two kinds of enterprises with property rights is less than $18 \%$. Among them, the proportion of women in state-owned enterprises is lower, $11.9 \%$, and that in non-state-owned enterprises is $17.6 \%$. The average degree of senior executives in state-owned and non-state-owned enterprises is 3.394 and 3.171 respectively.

\section{B. The correlation analysis of variables}

In order to test whether the correlation variables in the model have multicollinearity problems, Pearson correlation tests were carried out for independent variables, dependent variables and control variables of the research samples in this paper. The test results are shown in table III.

TABLE III. THE CORRELATION ANALYSIS OF VARIABLES

\begin{tabular}{|c|c|c|c|c|c|c|c|c|}
\hline & $\mathbf{F F}$ & $\begin{array}{c}\text { Female_Rat } \\
\text { e }\end{array}$ & $\begin{array}{c}\text { Avg_Ag } \\
\text { e }\end{array}$ & Avg_Degree & Size & ROE & Profit & $\begin{array}{l}\mathrm{I} \\
\mathrm{C} \\
\end{array}$ \\
\hline $\mathbf{F F}$ & 1 & & & & & & & \\
\hline $\begin{array}{l}\text { Female } \\
\text { Rate }\end{array}$ & $0.103^{* *+}$ & 1 & & & & & & \\
\hline Avg_Age & $0.164^{\circ \prime}$ & 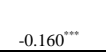 & 1 & & & & & \\
\hline $\begin{array}{l}\text { Avg_Deg } \\
\text { ree }\end{array}$ & $0.051^{\circ \prime}$ & $-0.040^{\ldots+*}$ & $-0.048^{\ldots \ldots}$ & 1 & & & & \\
\hline Size & $0.417^{\circ \prime}$ & $-0.110^{\circ * *+}$ & $0.276^{\ldots+*}$ & $0.242^{* * *}$ & 1 & & & \\
\hline ROE & $0.260^{\circ *}$ & $0.052^{* * *}$ & $-0.057^{+* * *}$ & 0.006 & $0.063^{* *}$ & 1 & & \\
\hline Profit & $0.360^{\circ \prime}$ & $0.067^{*+*}$ & $-0.062^{* * *}$ & 0.014 & 0.011 & $0.700^{* *}$ & 1 & \\
\hline IC & $0.167^{\circ+}$ & $0.025^{* * *}$ & $0.037^{\ldots *}$ & -0.0150 & $0.037^{* *}$ & $0.208^{* \prime}$ & $0.315^{* \prime}$ & 1 \\
\hline
\end{tabular}

As can be seen from table III, except the correlation coefficient between FF \& Size, Profit \& ROE are greater than 0.4 , the correlation coefficient between other variables are less than 0.4 , indicating that the correlation between variables are relatively low, indicating that there are no multi-collinearity between variables of the model, and further indicating that the selection of model variables is reasonable.

\section{Regression Analysis}

The regression results of samples in this paper are shown in tableIV. In the overall sample, the influence coefficient of the proportion of women in the executive team on financial flexibility is 0.130 , which is significant at the $1 \%$ level. That is to say, the higher the proportion of women in the executive team, the higher the financial flexibility of the enterprise. Hypothesis 1 is verified. The average age of the executive team is not correlated with the financial flexibility of the enterprise. Hypothesis 2 has not been verified and needs to be further tested. The regression coefficient between the average education background and financial flexibility of the executive team is 0.068 , which is significant at the $1 \%$ level, indicating that the higher the average educational backgrounds of the executive, the better the financial flexibility of the enterprise. Hypothesis 3 is tested. In the selected control variables, the regression coefficient between company size and enterprise financial flexibility is -0.309 , which is significant at the $1 \%$ level, indicating that the smaller the size of the enterprise, the better the financial flexibility. Return on equity, corporate profitability and net cash content of operating activities are all positively correlated with corporate financial flexibility, and all are significant at the level of $1 \%$.

The proportion of female executives in state-owned enterprises has a negative correlation with financial flexibility, 
which is not significant. However, non-state-owned enterprises are positively correlated, which is significant at the level of $1 \%$ This may be because women make up only $11.9 \%$ of senior managers in state-owned enterprises, too low to be accurate. However, the proportion of female executives in non-stateowned enterprises is higher, and the conclusion that the proportion of female executives is positively correlated with financial flexibility can be drawn, which verifies hypothesis 1 . The regression coefficients of the average age of senior executives and financial flexibility in state-owned enterprises and non-state-owned enterprises also come to different conclusions, which fully reflects the particularity of China's state-owned enterprises. In terms of the relationship between average education background and financial flexibility, the regression coefficients of both state-owned and non-stateowned enterprises are positive and the level of significance is consistent. The regression coefficients of various control variables and financial flexibility are different in enterprises with different property rights, but the correlation and significance levels are consistent.

TABLE IV. THE REGRESSION ANALYSIS OF VARIABLES

\begin{tabular}{|c|c|c|c|}
\hline Model & $\begin{array}{c}\text { The overall } \\
\text { sample }\end{array}$ & $\begin{array}{l}\text { State-owned } \\
\text { sample }\end{array}$ & $\begin{array}{l}\text { Non-state- } \\
\text { owned sample }\end{array}$ \\
\hline \multirow[t]{2}{*}{ Female_Rate } & $0.130^{* * *}$ & -0.045 & $0.183^{* * *}$ \\
\hline & [0.038] & [0.043] & {$[0.051]$} \\
\hline \multirow[t]{2}{*}{ Avg_Age } & -0.002 & 0.001 & -0.0003 \\
\hline & [0.002] & [0.002] & {$[0.002]$} \\
\hline \multirow[t]{2}{*}{ Avg_Degree } & $0.068^{* * * *}$ & $0.056^{* * *}$ & $0.080^{* * *}$ \\
\hline & [0.013] & [0.016] & {$[0.018]$} \\
\hline \multirow[t]{2}{*}{ Size } & $-0.309^{* * * *}$ & $-0.161^{* * *}$ & $-0.398^{* * *}$ \\
\hline & {$[0.006]$} & [0.007] & {$[0.009]$} \\
\hline \multirow[t]{2}{*}{ ROE } & $0.580^{* * *}$ & $1.093^{* * *}$ & $0.290^{* *}$ \\
\hline & [0.102] & [0.109] & {$[0.143]$} \\
\hline \multirow[t]{2}{*}{ Profit } & $1.953^{* * *}$ & $1.073^{* * *}$ & $2.294^{* * *}$ \\
\hline & {$[0.069]$} & {$[0.081]$} & {$[0.091]$} \\
\hline \multirow[t]{2}{*}{ IC } & $0.383^{* * *}$ & 0.014 & $0.528^{* * *}$ \\
\hline & [0.041] & [0.047] & {$[0.054]$} \\
\hline \multirow[t]{2}{*}{ cons } & $7.128^{* * *}$ & $3.974^{* * *}$ & $8.844^{* * *}$ \\
\hline & [0.153] & {$[0.176]$} & {$[0.238]$} \\
\hline Year & control & control & control \\
\hline Industry & control & control & control \\
\hline $\mathrm{N}$ & 12310 & 3982 & 8328 \\
\hline $\operatorname{adj.} R^{2}$ & 0.355 & 0.292 & 0.355 \\
\hline
\end{tabular}

\section{Robustness test}

In order to improve the robustness of the empirical results, the financial flexibility of dependent variables is calculated by using the measurement method of Zeng aimin [37].The results are shown in table $\mathrm{V}$ and table $\mathrm{VI}$
TABLE V. DESCRIPTIVE STATISTICS OF FINANCIAL FLEXIBILITY

\begin{tabular}{|l|c|c|}
\hline & N & Mean \\
\hline The overall sample & 9530 & 0.073 \\
\hline State-owned sample & 3386 & 0.028 \\
\hline Non-state-owned sample & 6144 & 0.097 \\
\hline
\end{tabular}

The average financial flexibility of non-state-owned enterprises is still higher than that of state-owned enterprises. In the regression results of the whole sample, the adjusted $R^{2}$ is 0.229 , indicating that the model has a good fitting degree. The regression coefficient between the proportion of women in the executive team and the financial flexibility of the enterprise is positive, but not significant. The regression coefficient between the average age and the financial flexibility of enterprises is negative and significant at the level of $1 \%$. The average educational background is positively correlated with the financial flexibility of enterprises, and the significance level is $1 \%$. Among the related control variables, the regression results of all variables and financial flexibility are significant at the level of $1 \%$. The above conclusions are basically consistent with the previous empirical research conclusions, indicating that the effect of executive background characteristics on financial flexibility is robust.

TABLE VI. ROBUSTNESS TEST RESULTS

\begin{tabular}{|l|c|c|}
\hline & Robustness test results & Primary regression results \\
\hline Female_Rate & 0.006 & $0.130^{* * *}$ \\
\hline Avg_Age & $-0.001^{* * *}$ & -0.002 \\
\hline Avg_Degree & $0.0116^{* * *}$ & $0.068^{* * *}$ \\
\hline
\end{tabular}

\section{CONCLUSION AND DISCUSSION}

First of all, in all samples, the proportion of female executives in the executive team has a positive impact on the financial flexibility of the enterprise, with a high level of significance. In the sample of state-owned enterprises, the ratio of women in the senior management team has a negative correlation with the financial flexibility of enterprises, which is related to the particularity of China's state-owned enterprises, and the particularity of state-owned enterprises weakens the influence of executive gender characteristics on the financial flexibility of enterprises. In the sample of non-state-owned enterprises, the coefficient is positive, which is consistent with the overall sample conclusion.

Secondly, in the sample of state-owned enterprises, the average age of senior management team has a positive but not significant impact on the financial flexibility of enterprises. The older the senior executives were, the more they understand the macro and micro environment of the enterprise, the easier they are to predict the existence of danger before the occurrence of enterprise crisis, and the more they tend to maintained a higher financial flexibility. In non-state-owned enterprises, the coefficient is negative and not significant. The regression coefficient between the average age of the executive team and the financial flexibility of the enterprise is negative, because in all samples, non-state-owned enterprises account for a large proportion. But overall, the average age of the executive 
team has no significant impact on the financial flexibility of the enterprise.

Finally, the average education level of senior executives in the sample of state-owned enterprises is higher than that of non-state-owned enterprises, which is attributed to the relatively perfect training and education system of state-owned enterprises in China. No matter in the sample of state-owned enterprises or non-state-owned enterprises, or in the overall sample, the average executive education level has a positive impact on the financial flexibility of enterprises, and the significance level is high. This indicates that the level of education has a significant impact on the financial flexibility of enterprises.

\section{ACKNOWLEDGMENTS}

FUND PROJECTS: This paper is the phased achievement of Jiangxi province graduate innovation special fund project (YC2019-318) in 2019 and Jiangxi University of Science and Technology innovation and entrepreneurship training project (DC2019-071).

\section{REFERENCES}

[1] Hambrick Donald C, Mason Phyllis A.Upper Echelons: The Organization as a Reflection of Its Top Managers.Academy of Management Review, 1984, 9(2):193-206.

[2] Krishnan HA,Park D.A few good women -on top management teams [J].Journal of Business Research,2005,58(12):1712-1720.

[3] He weifeng, Liu qiliang. Research on the background characteristics and financial restatement behaviors of senior executives in Chinese listed companies [J]. Management world,2010(07):144-155.

[4] SRINIDHI B, GUL FA, TSUI J.Female Directors and Earnings Quality[J].Contemporary Accounting Research,2011,28(5):1610-1644.

[5] Yang Lin, Yang qian. An empirical study on the relationship between the structural differences of senior management teams and enterprise mergers and acquisitions [J]. Scientific research management,2012,33(11):57-67.

[6] Zhang zhaoguo, Xiang shouren, Cao danting. Heterogeneity of executive team and corporate social responsibility--research on the role of behavioral integration based on budget management [J]. Management review, 2008,30(04):120-131.

[7] Waelchli U, Zeller J.Old captains at the helm: Chairman age and firm performance[J].Journal of Banking \& Finance,2013,37(5):1612-1628.

[8] Lu xin, Zhang lele, Li huimin, Ding yanping. Background characteristics and investment efficiency of executive team -- research on regulatory effect based on executive incentive [J]. Audit and economic research,2017,32(02):66-77.

[9] Li duansheng, Zhou hong. Characteristics of senior management teams, vertical pair feature differences and internal control quality [J]. Audit and economic research,2017,32(02):24-34.

[10] Smith KG, Smith KA, Sims Jr. HP, et al. Top Management Team Demography and Process: The Role of Social Integration and Communication[J].Administrative Science Quarterly, 1994,39(3):412438.

[11] Zhang ping. Research on the relationship between heterogeneity of senior management team and enterprise performance [J]. Management review, 2006(05):54-61+64.

[12] Yang ruiping, Liang zhangying. Research on the influence of background characteristics of senior management team on internal control -- evidence from listed real estate companies [J]. Economic issues,2016(09):102-106.

[13] Zhou hong, Li duansheng. Heterogeneity of executive team, CEO power and internal control quality of enterprises [J]. Journal of shanxi university of finance and economics, 2008,40(01):83-95.
[14] Graham,J.R.and Campbell R.H.The theory and practice of corporate finance: evidence from the field[J].Journal of Financial Economics, 2001, 61:187 243

[15] Ge jiashu, Zhan maisong. Several financial information -- liquidity, financial adaptability, expected cash inflow, profitability and market risk that must be paid attention to in the analysis of corporate financial reports [J]. Accounting research,2008(05):3-9+95.

[16] Gu naikang, Wan xiaoyong, Chen hui. Research on the relationship between financial flexibility and enterprise investment [J]. Management review,2011,23(06):115-121.

[17] MATTHEW T. BILLETT,JON A. GARFINKEL. Financial Flexibility and the Cost of External Finance for U.S. Bank Holding Companies[J].Journal of Money, Credit and Banking , 2004,Vol.36(NO.5) : 827-852.

[18] Gu naikang, Wan xiaoyong, Chen hui. Research on the relationship between financial flexibility and enterprise investment. Management review,2011,23(06):115-121.

[19] $\mathrm{Li}$ yan. The impact of enterprise life cycle on financial resilience. Journal of economic research,2013(15):164-165.

[20] Wang aiqun, Tang wenping. Research on the impact of environmental uncertainty on the relationship between financial flexibility and enterprise growth [J]. China soft science,2017(03):186-192.

[21] Ma chunai, Yi cai. Research on the impact of manager overconfidence on financial resilience [J]. Accounting research,2017(07):75-81+97.

[22] Lie E. Financial Flexibility, Performance, and the Corporate Payout Choice[J].Journal of Business, 2005,78(6):1-23.

[23] Marchica M-T, Mura R. Financial Flexibility, Investment Ability, and Firm Value: Evidence from Firms with Spare Debt Capacity[J].Financial Management (Wiley-Blackwell),2010,39(4):1339-1365.

[24] Gu naikang, Wan xiaoyong, Chen hui. Research on the relationship between financial flexibility and enterprise investment [J]. Management review,2011,23(06):115-121.

[25] Chen hongbing, Lian yujun. Influence of financial flexibility on investment level and efficiency of enterprises [J]. Economic management,2013,35(10):109-118.

[26] Ma chunai, Zhang yafang. Relationship between financial flexibility and company value [J]. Systems engineering,2013,3111:35-39.

[27] $\mathrm{Li}$ yue, Guo zeguang, $\mathrm{Li}$ chengyou et al. Impact analysis of financial flexibility on capital structure and its dynamic adjustment -- based on the empirical data of a-share listed companies in China [J]. Audit and economic research,2019,34(01):66-74

[28] Huang J, Kisgen DJ. Gender and corporate finance: Are male executives overconfident relative to female executives? [J]. Journal of Financial Economics, 2013108 (3) : 822-839.

[29] Lu xin, Li huimin, Chen shuohui. Research on executive background characteristics and financial fraud behaviors -- based on the empirical data of Chinese listed companies [J]. Audit and economic research,2015,30(06):58-68.

[30] Xu xixiong, Li xiaoqin. Executive gender, institutional environment and corporate CSR decision making [J]. Scientific research management, 2008,39(03):80-89.

[31] MF Wiersema, KA Bantel.Top Management Team Demography and Corporate Strategic Change[J].Academy of Management Journal,1992,35(1):91-121.

[32] He hongqu, Zhao tianzhe. Overconfidence of managers and overinvestment of enterprises -- based on the empirical evidence of listed companies in China [J]. Southern finance,2017(12):42-51.

[33] Sun Haifa, Yao zhenhua, Yan maosheng. Influence of demographic characteristics of executive team on business performance of textile and information technology companies [J]. Nankai management review,2006(06):61-67.

[34] Cao hongxia. Characteristics of chairman, investment behavior and corporate financial flexibility $[\mathrm{J}]$. Journal of finance and accounting,2017(29):29-36.

[35] Ma chunai, Han xinhua. Relationship between financial flexibility and investment efficiency based on different life cycles [J]. Systems engineering,2014,32(09):35-41. 
[36] Han jing, Chen zhihong, Yang xiaoxing. Research on the relationship between accounting robustness and investment efficiency from the perspective of background characteristics of senior management teams [J]. Accounting research,2014(12):25-31+95
[37] Zeng aimin, Fu yuanlou, Wei zhihua. Financial crisis impact, financial flexible reserve and corporate financing behavior -- empirical evidence from Chinese listed companies [J]. Financial research,2011(10):155-169. 